\title{
Bangunan PLTA Bengkok dan Dago Bandung
}

\author{
Iwan Hermawan \\ Balai Arkeologi Bandung \\ iwan1772@yahoo.com
}

\begin{abstract}
Abstrak, bangunan PLTA Bengkok dan PLTA Dago merupakan bangunan bersejarah peninggalan zaman kolonial Belanda. Pembangunannya dilakukan untuk memenuhi kebutuhan tenaga lisrik Kota Bandung. Bentuk dan fungsi bangunan PLTA Bengkok dan PLTA Dago serta teknologinya merupakan permasalahan yang diangkat dalam tulisan ini. Untuk menjawab permasalahan tersebut dipergunakan metode penelitian deskiptif. Pengumpulan data dilakukan dengan cara survei, wawancara, dan studi literatur. Bangunan-bangunan di PLTA Bengkok dan PLTA Dago dibangun sesuai dengan fungsinya dan kondisi lingkungan setempat.
\end{abstract}

Kata Kunci : rumah pembangkit, pipa pesat, kolam Pakar

Abstract, the Buildings of Bengkok Hydroelectric Power Plant (HEPP) and Dago HEPP are the heritage building of Dutch colonial period. Bengkok HEPP and Dago HEPP were built to fill electricity needs of Bandung city. Architecture and functions of Buildings, and its technology are issues in this paper. The descriptive research methods used to answer these issues. Data were collected through surveys, and interviews and literature studies. The Buildings at Bengkok HEPP and Dago HEPP were built according to its function and adapted to local environmental conditions.

Keywords : house of generator, penstock, Pakar's water reservoir

\section{Pendahuluan}

Bandung yang pada sebelum dibangunnya Jalan Raya Pos hanya sebuah kampung kecil di tengah belantara hutan tropis, pada awal abad ke-20 telah berubah menjadi salah satu kota penting di Hindia Belanda. Pada tahun 1884 kereta api sudah menghubungkan Bandung dengan Batavia melalui Cianjur dan Sukabumi, dan sepuluh tahun kemudian, tepatnya 1 November 
1894 kereta api menghubungkan Bandung dengan Cilacap. Keberadaan Kota Bandung sebagai salah satu kota penting semakin tampak ketika pada awal abad ke-20, tepatnya tahun 1906 kereta api mulai menghubungkan Bandung dengan Batavia melalui Purwakarta dan menjadikan waktu tempuh kedua kota semakin singkat.

Aktivitas warga kota yang semakin menggeliat tidak hanya di siang hari namun juga di malam hari menjadikan kebutuhan akan penerangan kota di malam hari menjadi kebutuhan yang harus dipenuhi pengelola kota. Awalnya penerangan malam di Kota Bandung dilakukan dengan menggunakan lentera-lentera minyak yang dipasang di tepi jalan dan pada akhir abad ke-19 lentera-lentera minyak tersebut diganti dengan lampu-lampu Gas (Kartodiwirio, 2006 : 400; Hutagalung dan Nugraha, 2008 : 101). Gas tersebut didistribusikan dari pabriknya di kawasan Kiaracondong dengan menggunakan jaringan pipa dan sekitar Statsiun Bandung merupakan kawasan yang pertama kali mendapatkan penerangan lampu Gas. Peran Gas sebagai sumber energi untuk penerangan kota tidak lama karena digantikan oleh energi listrik yang mulai dikembangkan di Kota Bandung pada dekade kedua abad ke-20. Energi listrik tersebut dihasilkan Pusat Listrik Tenaga Air (PLTA), yaitu Pusat Listrik yang menggunakan tenaga air atau "Batubara Putih" sebagai penggerak pembangkit (Suganda, 2007 : 87). Pengembangan PLTA untuk memenuhi kebutuhan tenaga listrik masyarakat Kota Bandung karena didukung oleh kondisi geografis dataran tinggi Bandung yang berbukit-bukit dan bergunung-gunung serta didukung oleh curah hujan yang tinggi sehingga air mengalir deras menuju tempat yang lebih rendah dengan debit air yang stabil karena hampir tidak ada bedanya antara aliran sungai di musim penghujan atau pun kemarau. Dewasa ini, energi air yang sudah dimanfaatkan untuk PLTA adalah seluruh aliran air dari daerah aliran Sungai Citarum yang ditampung Waduk Saguling (Bronto dan Hartono, 2006 :9)

Jauh sebelum tenaga air dimanfaatkan untuk menggerakkan PLTA, tenaga air telah berkontribusi banyak bagi pembangunan kesejahteraan manusia. Tenaga air telah dimanfaatkan para pendahulu kita sebagai penggerak kincir untuk kegiatan pertanian atau untuk menumbuk bahan makanan.

Pembangunan PLTA di kawasan Bandung dilakukan pada tahun 1906 di kawasan Pakar Dago dengan nama Waterkracht werk Pakar aan de Tjikapoendoeng nabij Dago atau PLTA Pakar dengan sumber airnya berasal dari Sungai Cikapundung. Listrik yang dihasilkan didistribusikan oleh Bandoengsche Electriciteits Maatschappy atau Perusahaan Listrik Bandung. Pada tahun 1920-an PLTA ini dibongkar diganti dengan PLTA yang lebih besar yaitu PLTA Bengkok. Bersamaan dengan pembangunan PLTA Bengkok, juga dibangun PLTA Dago yang sumber airnya adalah air buangan PLTA Bengkok. Hingga saat ini PLTA Bengkok dan Dago yang mulai beroperasi pada tahun 
1923 masih beroperasi dan menghasilkan tenaga listrik yang kemudian didistribusikan melalui jaringan kelistrikan Jawa - Bali. Pengelola kedua PLTA tersebut adalah PT Indonesia Power Unit Bisnis Pembangkit (UBP) Saguling yang merupakan anak perusahaan PT PLN Persero.

Berdasarkan lampiran Peraturan Daerah Kota Bandung No. 19 Tahun 2009 tentang Pengelolaan Kawasan dan Bangunan Cagar Budaya, Bangunan PLTA Dago Bengkok berada pada nomor urut 82 dari 99 bangunan dan kawasan yang dikategorikan sebagai Cagar Budaya di Kota Bandung (Lampiran Perda Kota Bandung No. 19 Tahun 2009). PLTA Bengkok dan Dago dengan peralatannya yang belum diganti sejak diresmikan pada tahun 1923 menjadikan PLTA ini sebagai pilihan mereka yang sedang mempelajari ilmu kelistrikan, khususnya bidang Pembangkit Tenaga Air. Hal ini terlihat dari banyaknya pelajar Sekolah Menengah Kejuruan (SMK) bidang listrik dan mahasiswa teknik elektro yang datang untuk mempelajari proses kerja PLTA. Tidak terbatas pada pelajar dan mahasiswa, masyarakat umum yang berminat mengembangkan pembangkit listrik tenaga mikro hydro juga banyak datang untuk belajar. Kondisi inilah yang menjadikan PLTA Bengkok dan Dago menarik untuk dibahas pada tulisan kali ini.

\section{Permasalahan dan Tujuan}

Kekhasan yang tampak pada PLTA Bengkok adalah bangunan dan teknologi pembangkit tenaga listrik yang terpasang di PLTA tersebut. Bangunan dan generator pembangkit yang terpasang belum mengalami perubahan yang berarti sejak PLTA ini didirikan pada tahun 1923. Berkenaan dengan uraian tersebut, permasalahan yang dibahas pada tulisan ini adalah bagaimana bentuk dan fungsi bangunan-bangunan di PLTA Bengkok dan PLTA Dago serta teknologi yang digunakannya?

Tulisan ini bermaksud menjawab permasalahan yang diajukan, yaitu berkenaan dengan aspek bentuk, dan fungsi bangunan serta teknologi Pembangkit Listrik yang dipergunakan PLTA Bengkok dan Dago. Ketiga aspek tersebut dibahas dengan mempertimbangkan lokasi PLTA dan aspek pemanfaatannya.

\section{Pusat Listrik Tenaga Air (PLTA)}

Pusat Listrik Tenaga Air (PLTA) merupakan pusat listrik dengan tenaga air sebagai sumber tenaga penggeraknya sehingga PLTA banyak dibangun di daerah dengan topografi bergunung-gunung dan berbukit-bukit, serta curah hujan yang tinggi. Hal ini dilakukan karena sungai di daerah ini airnya mengalir deras, bahkan di beberapa tempat terbentuk air terjun. Derasnya air yang 
mengalir di sungai secara alami tidak mampu menggerakkan turbin secara tetap dan stabil. Hal inilah yang mendorong pembangunan dam (bendungan) sebagai penampung air guna menjamin suplai air untuk menggerakkan turbin secara konstan walau di musim kemarau. Bagian utama dari sebuah PLTA terdiri dari bendungan/dam (water reservoir), pipa pesat (penstock), dan turbin air (water turbine). Selain itu, sebagai pendukung pusat listrik tenaga air ini digunakan beberapa alat bantu (auxiliary equipments) untuk membantu turbin air berjalan dengan baik, yaitu sistem pelumas (lube oil system), sistem pendingin (cooler system), sistem pengontrol udara (air control system), sistem udara (air service system), sistem hidrolik (hydraulic system) (Arismunandar dan Kuwahara, 1991).

Bendungan/dam (water reservoir) dibangun dengan tujuan untuk menahan aliran air sungai dan menampungnya. Air tersebut kemudian dialirkan melalui saringan power intake dan masuk ke pipa pesat (penstock) untuk merubah energi potensial menjadi energi kinetik. Pada ujung pipa pesat dipasang katup utama (main inlet valve) untuk mengalirkan air ke turbin. Katup utama ini akan tertutup otomatis bila terjadi gangguan dan ditutup secara manual ketika dilakukan perbaikan atau pemeliharaan rutin. Air yang telah mempunyai tekanan dan kecepatan tinggi diubah menjadi energi mekanik dengan dialirkan melalui sirip-sirip pengarah akan mendorong sirip jalan (runner) yang terpasang pada turbin. Energi yang diterima turbin selanjutnya digunakan untuk menggerakkan generator yang kemudian menghasilkan tenaga listrik. Air yang keluar dari turbin kemudian keluar melalui tail race untuk dibuang ke sungai. Pada dam/bendungan atau kolam penampung juga dilengkapi dengan pintu pelepas otomatis (spillway) untuk membuang kelebihan air pada saat air melimpah sehingga tinggi muka air di bendungan tidak melebihi batas maksimal daya tampung bendungan/dam atau kolam penampung (Arismunandar dan Kuwahara, 1991).

Bangunan PLTA Bengkok dan Dago merupakan bangunan yang dibangun pada tahun 1920-an dan arsitektur bangunannya disesuaikan dengan kondisi lingkungan setempat. Menurut Handinoto (1996), bentuk arsitektur kolonial Belanda di Indonesia sesudah tahun 1900 merupakan bentuk yang spesifik. Bentuk tersebut merupakan hasil kompromi dari arsitektur modern yang berkembang di Belanda pada waktu yang bersamaan dengan penyesuaian iklim tropis basah Indonesia. Ada juga beberapa bangunan arsitektur kolonial Belanda yang mengambil elemen-elemen tradisional setempat yang kemudian diterapkan ke dalam bentuk arsitekturnya. Hasil keseluruhan dari arsitektur kolonial Belanda di Indonesia tersebut adalah suatu bentuk khas yang berlainan dengan arsitektur modern yang ada di Belanda sendiri. 
Sebagai produkbudaya, arsitektur dipengaruhioleh(1) faktor lingkungan: geografis, geologis, iklim, dan suhu; (2) faktor teknologi: pengelolaan sumber daya, dan keterampilan teknis bangunan; dan (3) faktor budaya: falsafah, persepsi, religi, struktur social dan keluarga, dan ekonomi. Gaya bangunan setelah tahun 1920-an dikenal dengan nama niuwe bouwen atau arsitektur kolonial modern yang dipengaruhi oleh aliran International Style. Gaya arsitektur ini lebih mengutamakan segi fungsional dan telah disesuaikan dengan iklim dan lingkungan Indonesia (Handinoto, 1996). Gaya bangunan kolonial modern mempunyai ciri sebagai berikut: Denah bangunan pada arsitektur kolonial modern lebih bervariasi sesuai anjuran kreativitas dalam arsitektur modern; tampak bangunan lebih mencerminkan form follow function atau clean design; penggunaan beton sudah diperkenalkan terutama pada bangunan bertingkat; memungkinkan sistem konstruksi rangka; serta terdapat perbedaan mencolok pada denah dan tampak bangunan antara bangunan rumah tinggal dengan bangunan fasilitas umum karena fungsi bangunan akan mempengaruhi bentuk bangunan (Handinoto, 2010: 145147).

\section{Metode Penelitian}

Untuk menjawab permasalahan yang diajukan, metode penelitian yang dipergunakan dalam penelitian ini adalah metode penelitian deskriptif. Hal ini dilakukan karena penelitian deskriptif memberikan gambaran lengkap tentang objek yang diteliti. Pengumpulan data dilakukan dengan cara survei ke PLTA Bengkok dan Dago, serta melakukan studi pustaka terhadap berbagai literatur pendukung.

\section{Kondisi Geografis Kawasan PLTA}

Kota Bandung secara geomorfologis berada pada Zona Depresi Antar Montana atau Zona Bandung yang merupakan zone pemisah atau zona antara Pegunungan Utara dan Pegunungan Selatan Pulau Jawa, di mana kedua pegunungan tersebut berelief tajam dengan pegunungan tinggi dan jurang yang dalam (Bemmelen, 1949), berada pada ketinggian rata-rata 768 $\mathrm{m}$ dpl dengan titik tertinggi di daerah Bandung Utara berada pada ketinggian $1.050 \mathrm{~m}$ dpl, dan titik terendah berada di bagian Selatan Kota Bandung pada ketinggian $675 \mathrm{~m}$ dpl. Topografi bagian utara Kota Bandung berbukit-bukit serta relatif datar di bagian pusat kota dan selatan Kota Bandung.

Secara geografis PLTA Bengkok dan Dago berada pada daerah hulu Sungai Cikapundung. Kawasan ini masuk dalam wilayah Taman Hutan Raya Ir. Juanda dengan ketinggian $\pm 770 \mathrm{~m}$ dpl sampai dengan $\pm 1350 \mathrm{~m}$ dpl. Ekosistemnya 
sebagian besar merupakan ekosistem pinggir sungai (riparian ecosystem). Memiliki tingkat kemiringan lereng (slope) dari agak curam sampai dengan terjal. Sungai Cikapundung merupakan anak Sungai Citarum yang berhulu di Gunung Bukittunggul, selain itu terdapat juga beberapa mata air yang bersumber dari kelompok Hutan Gunung Pulosari, membentang sepanjang $15 \mathrm{~km}$ dan lebar rata-rata 8 meter dengan debit air sekitar $3.000 \mathrm{~m}^{3}$ / detik. Keadaan iklim di kawasan Taman Hutan Raya Ir. Juanda berdasarkan pembagian iklim menurut Schmidt Ferguson termasuk Type B, kelembaban nisbi udara berkisar antara $70 \%$ (siang hari) dan $90 \%$ (malam dan pagi hari), suhu berkisar antara $22^{\circ} \mathrm{C}-24^{\circ} \mathrm{C}$ (di lembah) dan berkisar $18^{\circ} \mathrm{C}-22^{\circ} \mathrm{C}$ (di puncak). Curah hujan rata-rata pertahun $2.500-4.500 \mathrm{~mm} /$ tahun (http:// tahuradjuanda.jabarprov.go.id).

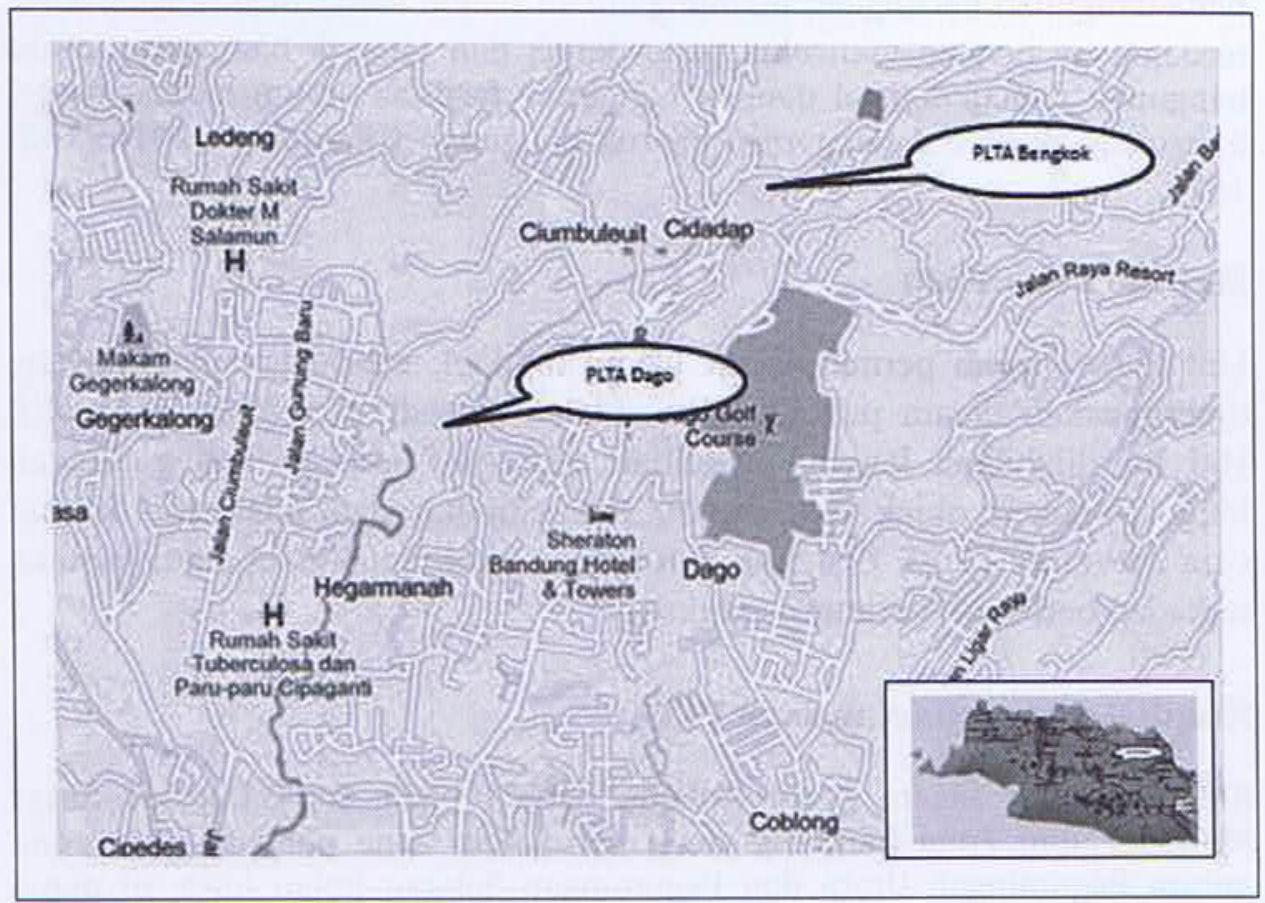

Gambar 1. Lokasi PLTA Bengkok dan PLTA Dago

\section{PLTA di Kota Bandung}

Pemanfaatan tenaga air untuk menggerakkan pembangkit tenaga listrik di Bandung dimulai pada tahun 1906, yaitu ketika diresmikannya PLTA Pakar dengan nama Waterkracht Werk Pakar aan de Tjikapoendoeng Nabij Dago yang berlokasi di lembah Sungai Cikapundung dan memanfaatkan aliran air Sungai Cikapundung sebagai tenaga penggerak turbinnya. Daya listrik 
dihasilkannya sebesar $800 \mathrm{~kW}$ dan didistribusikan ke masyarakat Bandung oleh Perusahaan Listrik Bandung (Bandungte Electriciteits Maastchappy). Perkembangan kelistrikan di Kota Bandung selanjutnya, adalah pada tahun 1920 didirikan Perusahaan Listrik Umum Bandung dan sekitarnya (Gemeenschappelijke Electriciteits Bedrijven Bandung en Omstreken/GEBEO). Perusahaan ini didirikan secara patungan oleh pemerintah dan swasta, yaitu NV Maintz \& Co. GEBEO mengambil alih pengelolaan PLTA Pakar di Bandung dan PLTA Cijedil di Cianjur, kemudian bekerja sama dengan Perusahaan Listrik Negara memasok listrik kepada masyarakat luas (PLN, t.t.; Suganda, 2008: 88).

Perusahaan Tenaga Air Negara Dataran Tinggi Bandung (Landis waterkrafcht Bedijf Bandung en Electricitieit) mempunyai dua kelompok PLTA, yaitu PLTA Bengkok yang berkekuatan $3 \times 1050 \mathrm{~kW}$, dan PLTA Dago dengan kekuatan $1 \times 700 \mathrm{~kW}$ yang diresmikan pada tahun 1923 berada di Sungai Cikapundung, serta PLTA Plengan $(3 \times 1050 \mathrm{~kW})$ yang mulai beroperasi pada tahun 1923, dan Lamajan ( 2 × $6400 \mathrm{~kW}$ ) pada tahun 1924 di Sungai Cisangkuy dan Cisarua.

\section{Karakteristik PLTA Bengkok dan PLTA Dago}

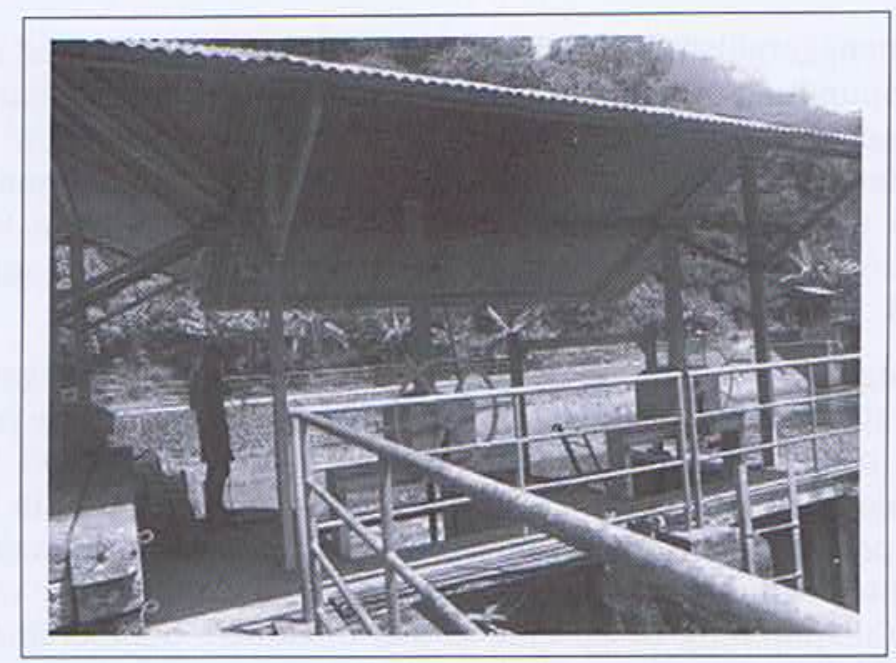

Gambar 2. Bangunan dam Bantarawi (Dok. Hermawan, 2012)

PLTA Bengkok dan Dago yang didirikan pada tahun 1923 berlokasi di lembah Sungai Cikapundung dan memanfaatkan air dari sungai tersebut sebagai sumber tenaga penggerak turbinnya. Kedua PLTA tersebut hingga saat ini berfungsi dan memproduksi listrik yang didistribusikan melalui jaringan interkoneksi Jawa - Bali. Bangunan yang dibangun untuk menunjang PLTA 
tersebut, adalah bendungan/dam, kolam penampung, kolam pengendap, rumah pembangkit, dan saluran.

Berkenaan dengan keberadaan pemanfaatan air Sungai Cikapundung untuk kepentingan PLTA Bengkok dan Dago, Iman Suherman, pimpinan di PLTA Bengkok, menjelaskan bahwa efektivitas pemanfaatan air untuk menghasilkan tenaga listrik telah dilakukan di PLTA Bengkok dan Dago. Air yang disadap dari Sungai Cikapundung ditampung di sebuah kolam penampung, kemudian dialirkan dengan saluran tertutup ke kolam pengendap (kolam Pakar). Dari kolam ini, kemudian air dialirkan melalui pipa pesat ke PLTA untuk menggerakkan turbin. Setelah melalui dan menggerakkan turbin, air dibuang kembali ke sungai. Di PLTA Bengkok, air buangan tersebut tidak langsung dibuang ke sungai tetapi langsung masuk ke saluran untuk dialirkan ke PLTA Dago yang ketinggiannya lebih rendah dibanding PLTA Bengkok. Di ujung saluran, air ditampung dalam sebuah bak tertutup, kemudian dialirkan ke pipa pesat yang mengalirkannya ke mesin PLTA Dago. Setelah memutar turbin di PLTA Dago, air limpasan dimanfaatkan oleh PDAM sebagai air baku untuk memenuhi kebutuhan air bersih masyarakat Kota Bandung dan sisanya kembali ke Sungai Cikapundung.

\section{Bendungan/Dam Bantarawi}

Air untuk menggerakkan turbin PLTA Bengkok dan Dago diambil dari aliran Sungai Cikapundung. Air ini disadap oleh bendungan yang dibangun pada aliran sungai di daerah Bantarawi, terletak pada koordinat $06^{\circ} 50^{\prime} 37,7^{\prime \prime}$ Lintang Selatan (LS) dan $107^{\circ} 38^{\prime}$ 56,8' Bujur Timur (BT). Pembangunan Bendungan di aliran Sungai Cikapundung tersebut dilakukan bersamaan dengan pembangunan PLTA Bengkok dan Dago yang mulai beroperasi pada tahun 1923.

Bendungan ini mempunyai dua pintu air untuk mengatur tinggi rendahnya air, satu pintu difungsikan sebagai pengatur aliran air yang masuk ke saluran penghubung dengan kolam penampung di Bantarawi. Satu pintu air merupakan saluran pelimpas untuk membuang ait berlebih ke sungai. Pada saat pembersihan kolam, pintu air yang mengarah ke saluran akan ditutup. Pintu air limpasan akan dibuka maksimal jika debit air yang masuk ke Sungai Cikapundung tinggi atau ketika dilakukan pembersihan saluran yang rutin dilakukan setiap tiga bulan sekali.

\section{Kolam Penampung Bantarawi}

Air sadapan dari bendungan (dam) di aliran air Sungai Cikapundung dialirkan ke kolam penampung yang dibangun tidak jauh dari lokasi bendungan (dam), yaitu di Bantarawi sebelum akhirnya dialirkan ke kolam pengendap yang berada di Pakar. Kolam penampung terletak pada koordinat $06^{\circ} 50^{\prime} 49,8^{\prime \prime}$ 
Lintang Selatan dan $107^{\circ} 38^{\prime} 43,3^{\prime \prime}$ Bujur Timur. Luas kolam penampung adalah $200 \mathrm{~m}^{2}$ dengan kedalaman $3,3 \mathrm{~m}$.

Kolam penampung di Bantarawi juga berfungsi sebagai penyaring air tahap pertama, tujuannya agar sampah-sampah berukuran besar berupa batang kayu, ranting pohon, dan sampah lainnya dari sungai tidak terbawa masuk ke saluran yang menuju ke kolam pengendap. Secara rutin kolam ini dikuras airnya guna membersihkan lumpur yang mengendap di dasar kolam, tujuannya agar kapasitas kolam tidak berkurang akibat menumpuknya endapan lumpur.

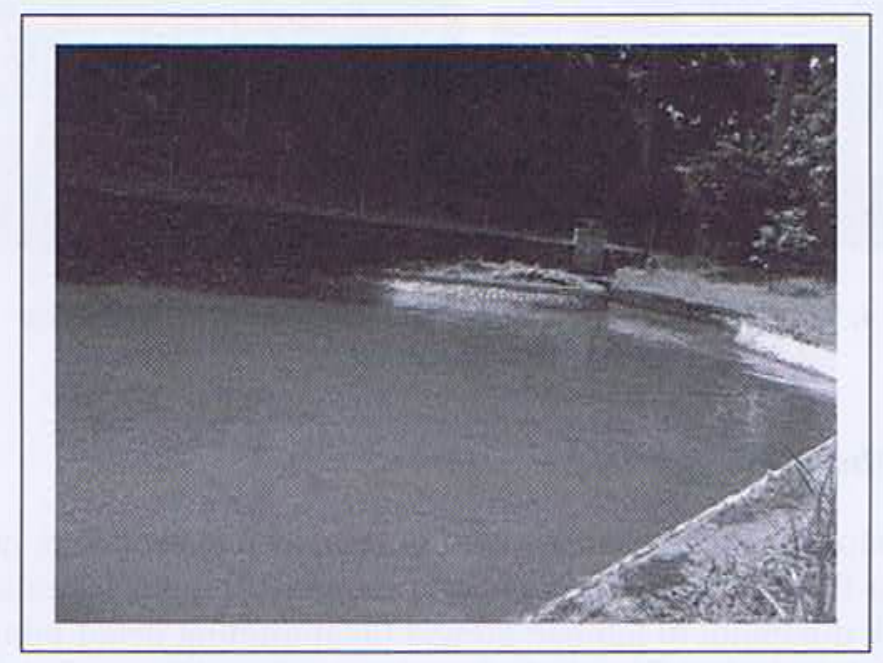

Gambar 3. Kolam Bantarawi (Dok. Hermawan, 2012)

\section{Kolam Pengendap}

Air Sungai Cikapundung yang disadap oleh dam Bantarawi dan ditampung di kolam Bantarawi kemudian disalurkan ke kolam penampung berikutnya atau kolam pengendap yang dibangun di Kampung Pakar. Lokasi dibangunnya kolam pengendap tepat berada di atas PLTA Bengkok dengan beda ketinggian 102 m, terletak pada koordinat $06^{\circ} 51^{\prime} 33,2^{\prime \prime}$ LS dan $107^{\circ} 37^{\prime} 45,1^{\prime \prime}$ BT dan memiliki peil $920,40 \mathrm{~m}$ dpl dengan peil maksimum $+3,06 \mathrm{~m}$. Luas kolam Pakar adalah $8.935 \mathrm{~m}^{2}$ dan mampu menampung air sebanyak $30.000 \mathrm{~m}^{3}$. Peil minimum kolam pengendap, adalah $920,40 \mathrm{~m}$ dpl dengan peil maksimum + $3,06 \mathrm{~m}$ dan peil lantai Pembangkit PLTA Bengkok adalah $818,20 \mathrm{~m}$ dpl (PT Indonesia Power UBP Saguling sub unit PLTA Bengkok, 2012).

Air yang sudah menggerakkan turbin di PLTA Bengkok selanjutnya dialirkan untuk kembali menggerakkan turbin di PLTA Dago melalui saluran tertutup. Sebelum sampai di turbin PLTA Dago, air ditampung di sebuah 
bak penampungan yang dibangun di ujung saluran. Bak penampungan ini mempunyai peil minimum $808,00 \mathrm{~m}$ dpl dan peil maksimum $+1,40 \mathrm{~m}$. Air dari bak penampungan inilah yang kemudian dialirkan ke pipa pesat untuk kemudian menggerakkan turbin (PT Indonesia Power UBP Saguling sub unit PLTA Bengkok, 2012).

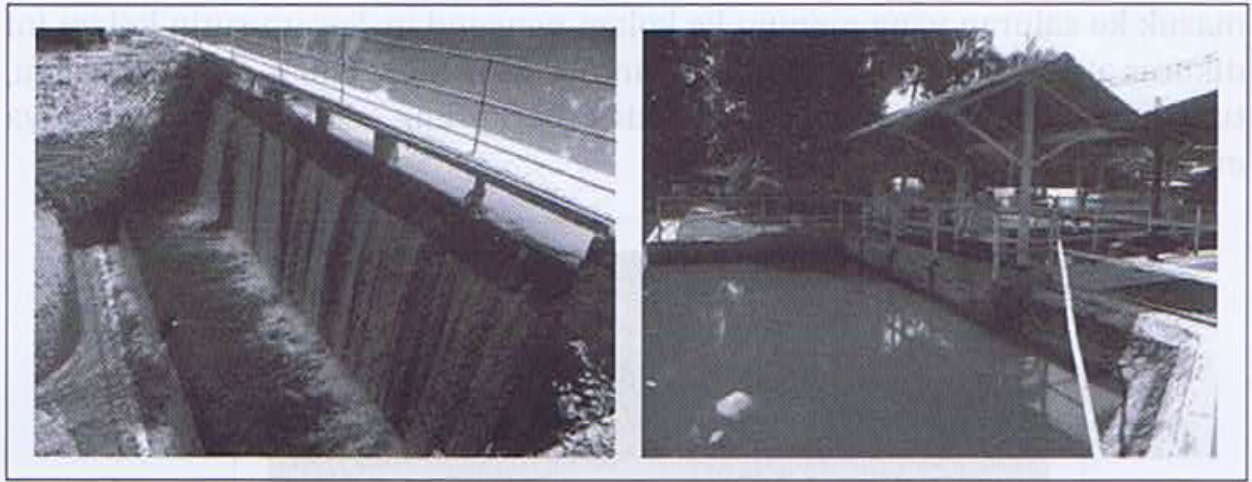

Gambar 4. Saluran pelimpas di kolam Pakar dan pintu air kolam Pakar (Dok. Hermawan, 2012)

\section{Rumah Pembangkit}

Rumah pembangkit merupakan bangunan tempat mesin turbin, generator, dan peralatan PLTA lainnya ditempatkan. Bangunan rumah pembangkit di PLTA Bengkok dibangun di lembah Sungai Cikapundung dekat tebing terjal. Lokasinya tidak jauh dari jalan Ir. H. Juanda atau Jalan Dago, tepatnya pada koordinat $06^{\circ} 51^{\prime} 41,6^{\prime \prime}$ LS dan $107^{\circ} 37^{\prime} 27,7^{\prime \prime}$ BT. Secara geografis berada di kawasan Pakar - Dago Bandung. Untuk memasuki kompleks PLTA Bengkok tidaklah sulit karena dari jalan Ir. H. Juanda dihubungkan oleh jalan yang dapat dilalui kendaraan bermotor roda empat. Di kompleks ini terdapat dua bangunan utama PLTA, yaitu bangunan yang dipergunakan sebagai kantor PLTA dan bangunan rumah pembangkit, serta mess PT Indonesia Power yang dilengkapi dengan fasilitas ruang rapat.

Bangunan rumah pembangkit PLTA Bengkok berdenah persegi empat, dengan dinding tembok yang terbuat dari susunan batu kali dengan ketebalan lebih dari $30 \mathrm{~cm}$. Pada bagian dinding tertentu, susunan batu kali dibiarkan tidak dilepas sehingga struktur batunya terlihat jelas, dinding bagian dalam bangunan dilepa dan lantainya dilapisi tegel, sedang di ruang tempat terpasangnya mesin lantainya dilapisi keramik warna merah. Pintu masuk bangunan berukuran tinggi dan lebar (tiap pintu terdiri ditutup dengan dua daun pintu). Demikian pula dengan jendela, ukurannya tinggi dan lebar (tiap jendela ditutup oleh dua daun jendela) serta dilengkapi dengan lubang 
ventilasi udara di atas pintu dan jendela. Atap bangunan merupakan atap umpak berbentuk limas dan ditutup oleh seng.

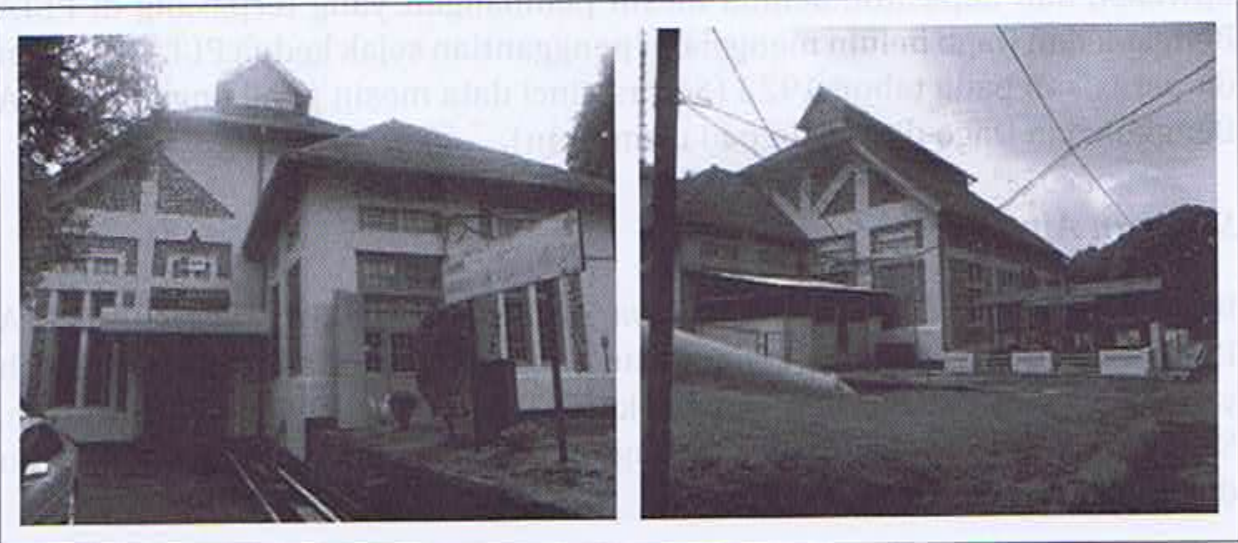

Gambar 5. Tampak depan dan belakang bangunan rumah pembangkit PLTA Bengkok

(Dok. Hermawan, 2012)

Ruangan-ruangan di bagian dalam rumah pembangkit PLTA Bengkok dibangun dengan ukuran berbeda disesuaikan dengan peralatan pembangkit yang dipasang. Semua peralatan pembangkit dipasang dengan cara ditanam di dinding atau di lantai. Ruangan tempat dipasangnya mesin pembangkit dibangun dengan kedap suara sehingga suara bising mesin pembangkit tidak sampai terdengar keras ke ruangan lain atau bahkan ke luar gedung. Di rumah pembangkit dipasang tiga unit mesin pembangkit yang semuanya dipasang tahun 1923.

Bangunan rumah pembangkit lainnya, adalah rumah pembangkit PLTA Dago yang letaknya terpisah dari kompleks bangunan PLTA Bengkok. Secara administratif, rumah pembangkit PLTA Dago berada di wilayah Kota Bandung, tepatnya di kawasan Dago Pojok. Untuk mencapainya, dari jalan desa dihubungkan dengan tangga yang terbuat dari tembok berbahan dasar batu kali. Tangga tersebut dibangun berdampingan dengan pipa pesat. Bentuk dasar bangunannya persegi empat dengan dinding tembok yang terbuat dari susunan batu kali yang dilepa. Pada bagian tertentu dibiarkan tidak dilepa sehingga struktur batunya terlihat jelas. Pintu dan jendela yang melengkapi bangunan berkuran tinggi serta dilengkapi dengan ventilasi di atas pintu dan jendela. Ukuran bangunan rumah pembangkit PLTA Dago tidak sebesar dan seluas PLTA Bengkok, karena di PLTA Dago hanya ditempatkan satu mesin pembangkit yang pengoperasiannya dikoordinir PLTA Bengkok.

Berdasarkan keterangan dari Iman Suherman, Senior Supervisor di PLTA Bengkok, mesin pembangkit yang dioperasikan PLTA Bengkok dan Dago 
berjumlah empat unit, yaitu tiga unit di PLTA Bengkok dan satu unit di PLTA Dago. Masing-masing unit pembangkit terdiri dari turbin, generator, exeiter/ opweker, dan kapasitor. Semua mesin pembangkit yang terpasang di PLTA Bengkok dan Dago belum mengalami penggantian sejak kedua PLTA ini mulai dioperasikan pada tahun 1923 (Secara rinci data mesin pembangkit di PLTA Bengkok dan Dago diuraikan pada lampiran).

\section{Saluran Air}

Bagian yang tidak kalah pentingnya dari sebuah PLTA, termasuk PLTA Bengkok dan Dago, adalah keberadaan bangunan saluran air. Saluran inilah yang menyalurkan air dari sungai ke PLTA untuk menggerakkan turbin. Saluran air di PLTA Bengkok dan Dago terdiri dari dua jenis, yaitu saluran dan pipa pesat.

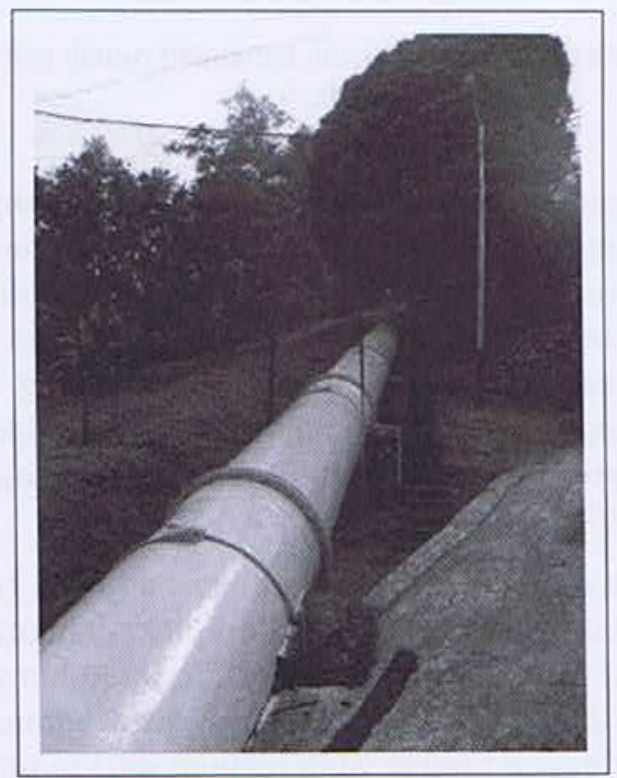

Gambar 6. Pipa pesat PLTA Bengkok lama,sekarang sudah tidak difungsikan (Dok. Hermawan, 2012)

Saluran air yang menghubungkan kolam penampung di Bantarawi dengan kolam pengendap di Pakar berbahan beton berbentuk tapal kuda, memiliki panjang $2.731 \mathrm{~m}$ dengan kapasitas $3,0 \mathrm{~m}^{3} /$ detik dengan posisi peil awal $930 \mathrm{~m}$ dpl dan peil akhir $923,46 \mathrm{~m}$ dpl. Saluran lainnya, adalah saluran yang menghubungkan PLTA Bengkok denga PLTA Dago. Saluran ini dibangun dengan bentuk tapal kuda berbahan beton memiliki panjang $1.400 \mathrm{~m}$ dengan kapasitas $3,0 \mathrm{~m}^{3} /$ detik dengan posisi peil awal $813,30 \mathrm{~m}$ dpl dan peil akhir $809,84 \mathrm{~m}$ dpl. Saluran-saluran ini dibangun pada tahun 1922 dan hingga 
saat ini masih dipergunakan (PT Indonesia Power UBP Saguling sub unit PLTA Bengkok, 2012). Pada awalnya di kawasan perbukitan Pakar, Air dari Bantarawi dialirkan melalui terowongan sepanjang 144 meter lebar 1,8 m dan tnggi 3,20 m, namun pada waktu Perang Dunia II, tahun 1941, kawasan Perbukitan Pakar dijadikan sebagai pertahanan Belanda dan saluran air tersebut diubah fungsinya menjadi stasiun radio dengan membangun 15 lorong dan dua pintu masuk. Air dialirkan ke saluran di samping gua Belanda yang sekarang masih difungsikan (http://tahuradjuanda. jabarprov.go.id).

Pipa Pesat, merupakan saluran penyalur air yang langsung masuk ke PLTA. Keberadaan pipa pesat bagi PLTA merupakan suatu yang vital, karena pipa tersebut merupakan penyalur air untuk menggerakkan turbin. Pipa pesat biasanya dipasang dengan kemiringan yang ekstrem, tujuannya agar air yang mengalir masuk ke turbin mempunyai kecepatan yang tinggi.

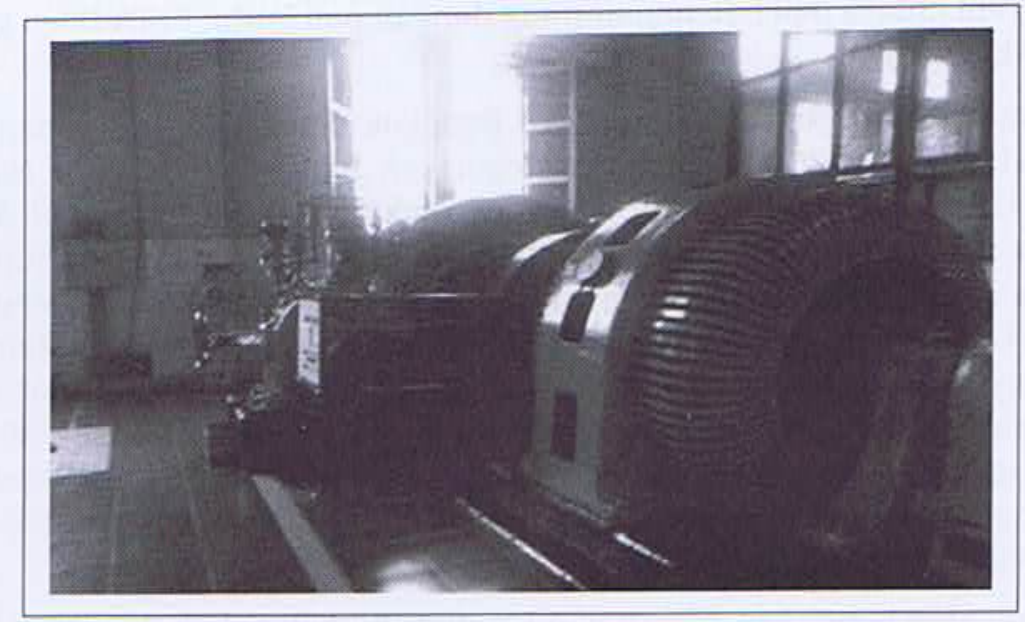

Gambar 7. Mesin Pembangkit PLTA Bengkok (Dok. Hermawan, 2012)

Kolam Pengendap (kolam Pakar) mempunyai peil minimum 920,4 m dpl dan peil Lantai PLTA Bengkok, adalah $818,20 \mathrm{~m}$ dpl. Air dari kolam pengendap ke PLTA dihubungkan dengan sebuah pipa pesat yang panjangnya $635 \mathrm{~m}$ dan memiliki kapasitas $4,50 \mathrm{~m}^{3} /$ detik. Ketika pertama didirikan pada tahun 1923, pipa pesat PLTA Bengkok dibangun dengan menggunakan bahan logam (pipa besi) namun akibat korosi menyebabkan kapasitas pipa menurun dan pada tahun 1983 dibangun pipa baru dengan bahan beton berdampingan dengan pipa lama. Peil minimum kolam pengendap PLTA Dago adalah 808,00 $\mathrm{m}$ dpl dan peil lantai PLTA Dago 767,85 m dpl. Air dari kolam pengendap dialirkan melalui pipa pesat yang panjangnya $124 \mathrm{~m}$, berbahan beton dengan kapasitas $4,50 \mathrm{~m}^{3} /$ detik. Pipa ini dibangun pada tahun 1923 bersamaan dengan dibangunnya PLTA (PT Indonesia Power UBP Saguling sub unit PLTA Bengkok, 2012). 


\section{Pembahasan}

PLTA Bengkok dan Dago merupakan PLTA yang dibangun di Dataran tinggi Bandung dengan maksud untuk memenuhi kebutuhan tenaga listrik Kota Bandung. Kebutuhan akan tenaga listrik tersebut mencakup kebutuhan untuk kepentingan umum, yaitu penerangan jalan-jalan utama di Kota Bandung dan fasilitas kota lainnya, serta kebutuhan tenaga listrik untuk permukiman, khususnya permukiman warga Eropa di Kota Bandung.

Sebagaimana PLTA lainnya, PLTA Bengkok dan Dago dibangun dengan memanfaatkan tenaga aliran air yang terjadi akibat pengaruh topografi dataran tinggi Bandung yang berbukit-bukit dan bergunung-gunung. Hal ini tampak pada perbedaan ketinggian peil yang ekstrem antara peil kolam Pakar yang merupakan kolam pengendap dengan peil lantai PLTA Bengkok yang berada di bawahnya. Demikian pula halnya perbedaan ketinggian peil yang ekstrem antara peil bak penampung dengan peil lantai PLTA Dago yang berada di bawahnya.

Secara arsitektural, bangunan PLTA Bengkok dan Dago yang dibangun pada awal tahun 1920-an dapat dikategorikan bangunan bergaya Niuwe Bouwen. Gaya arsitektur ini dipengaruhi oleh aliran International Style dan lebih mengutamakan segi fungsional disesuaikan dengan lingkungan Indonesia (Handinoto, 1996). Bangunan rumah pembangkit PLTA Bengkok dan PLTA Dago dibangun sesuai dengan fungsi yang dimilikinya, yaitu tempat dipasangnya mesin-mesin pembangkit tenaga listrik. Hal ini terlihat dari pembagian ruang bangunan yang disesuaikan dengan kebutuhan alat-alat yang terpasang, serta konstruksi bangunannya disesuaikan dengan kondisi geologi dan morfologi dataran tinggi Bandung yang rawan gempa dan bencana vulkanik.

Bentuk atap bangunan rumah pembangkit PLTA Bengkok dan Dago juga dipengaruhi oleh kondisi lingkungan setempat yang bercurah hujan tinggi sepanjang tahun. Kondisi ini terlihat pada atap bangunan yang berbentuk limas umpak dan ditutup seng, karena bentuk atap demikian memudahkan air hujan mengalir lancar.

Letak rumah pembangkit PLTA Bengkok dan Dago yang ditempatkan tepat di bawah tebing terjal lembah Cikapundung. Di atas tebing tempat berdirinya rumah pembangkit PLTA Bengkok, adalah kolam Pakar yang merupakan kolam pengendap, sedangkan tepat di atas rumah pembangkit PLTA Dago adalah bak pengendap air sebelum disalurkan melalui pipa pesat. Penempatan bangunan rumah pembangkit tersebut didasarkan pada alasan bahwa sumber tenaga untuk menggerakkan mesin PLTA, adalah tenaga aliran air yang berkecepatan tinggi yang disalurkan melalui pipa pesat dari kolam atau bak pengendap ke mesin pembangkit yang dipasang di PLTA. Aliran air bercepatan tinggi tersebut terjadi akibat gaya gravitasi bumi. 


\section{Simpulan}

Berdasarkan pembahasan tersebut di atas, permasalahan berkaitan dengan bentuk dan fungsi bangunan rumah pembangkit di PLTA Bengkok dan Dago dapat dijawab. Berdasarkan data yang diperoleh dapat disimpulkan bahwa lokasi yang dipilih sebagai tempat didirikannya PLTA Bengkok dan Dago merupakan lokasi yang tepat bagi sebuah PLTA karena berada di daerah hulu sungai dengan curah hujan tinggi sepanjang tahun dan memiliki topografi berbukit-bukit dengan kemiringan lereng yang curam.

Bangunan rumah pembangkit PLTA Bengkok dan PLTA Dago dibangun sesuai dengan fungsi yang dimilikinya, yaitu tempat dipasangnya mesinmesin pembangkit tenaga listrik. Hal ini terlihat dari pembagian ruang bangunan yang disesuaikan dengan kebutuhan alat-alat yang terpasang, serta konstruksi bangunannya disesuaikan dengan kondisi geologi dan morfologi dataran tinggi Bandung yang rawan gempa dan bencana vulkanik

Bangunan rumah pembangkit PLTA Bengkok dibangun di lembah Sungai Cikapundung tepat di bawah bukit terjal yang di atasnya terdapat kolam Pakar yang merupakan kolam pengendap dan bangunan rumah pembangkit PLTA Dago dibangun di lembah Sungai Cikapundung di bawah dinding sungai yang terjal, tepat di atasnya terdapat kolam pengendap. Hal ini dikarenakan tenaga air dengan kecepatan tinggi diperlukan untuk menggerakkan mesinmesin pembangkit tenaga listrik.

Pada awal pembangunannya, keberadaan PLTA Bengkok dan Dago mempunyai peran yang sangat penting dalam perkembangan Kota Bandung. Perubahan penggunaan lahan di bagian hulu Sungai Cikapundung menyebabkan PLTA Bengkok dan Dago mulai terganggu pasokan airnya. Kualitas air yang semakin keruh menyebabkan semakin tingginya tingkat sedimentasi di kolam dan bak pengendap yang tentunya akan berpengaruh terhadap volume air yang ditampung dan disalurkan ke pembangkit. Kondisi ini jika tidak memperoleh perhatian serius semua elemen masyarakat dan pemerintah akan semakin mengancam keberadaan PLTA Bengkok dan Dago.

\section{Saran}

Sebagai bangunan Cagar Budaya yang hingga saat ini masih berproduksi dan dimanfaatkan bagi pengembangan Ilmu Pengetahuan, khususnya teknik kelistrikan, PLTA Bengkok an Dago perlu mendapat perlindungan agar operasionalnya tidak sampai berhenti atau dihentikan akibat tidak terpenuhinya pasokan air untuk menggerakkan PLTA. Aturan yang mengikat serta ketegasan pemerintah daerah dan pusat dalam penerbitan Izin Pengelolaan wilayah dan perubahan tata guna lahan, serta kesadaran masyarakat sekitar dalam mengelola sumber air akan dapat membantu tetap beroperasinya PLTA Bengkok dan Dago. 


\section{Daftar Pustaka}

Arismunandar, A dan S. Kuwahara. 1991. Teknik Tenaga Listrik Jilid 1. Jakarta: Pradnya Paramitha.

Bemmelen, R.W. van. 1949. The Geology of Indonesia. The Hague: Martinus Nijhoff.

Bronto, Sutikno dan Udi Hartono. 2006. Potensi Sumber daya Geologi di Daerah Cekungan Bandung dan Sekitarnya. Jurnal Geologi Indonesia. Vol. 1. No. 1. Maret 2006 (p. 9-18)

Budihardjo, Eko. 1991. Arsitektur dan Kota di Indonesia. Bandung: Alumni.

Handinoto. 1996. Perkembangan Kota dan Arsitektur Kolonial Belanda di Surabaya 1870-1940. Diterbitkan atas Kerja Sama Lembaga Penelitian dan Pengabdian Kepada Masyarakat Universitas Kristen Petra Surabaya dan Penerbit Andi. Yogyakarta: Andi Offset.

Handinoto. 2010. Arsitektur dan Kota-Kota di Jawa pada Masa Kolonial. Yogyakarta : Graha Ilmu.

Hutagalung, Ridwan dan T. Nugraha. 2008. Braga, Jantung Parijs van Java. Jakarta: Ka Bandung.

PT Indonesia Power UBP Saguling Sub Unit PLTA Bengkok. 2012. Data Mesin di PLTA Bengkok dan PLTA Dago.

Kartodiwirio, Sudarsono K. 2006. Bandung: Kilas Peristiwa di Mata Filatelis, Sebuah Wisata Sejarah. Bandung: Kiblat Buku Utama.

PLN. tt. Sejarah PLN Jawa Barat.

Suganda, Her. 2008. Jendela Bandung, Pengalaman Bersama Kompas. Jakarta: Kompas.

Taman Hutan Raya Ir: Juanda. (online) dalam http://tahuradjuanda. jabarprov. go.id [diunduh 10-07-2012]

\section{Lampiran}

Tabel 1

Data Turbin di PLTA Bengkok dan Dago

\begin{tabular}{|l|l|l|l|l|}
\hline \multirow{2}{*}{} & \multicolumn{3}{|c|}{ PLTA Bengkok } & \multicolumn{1}{c|}{ PLTA Dago } \\
\cline { 2 - 5 } & \multicolumn{1}{|c|}{ Mesin 1 } & \multicolumn{1}{c|}{ Mesin 2 } & \multicolumn{1}{c|}{ Mesin 3 } & \multicolumn{1}{c|}{ Mesin 4 } \\
\hline Merek & ESSCHER WYSS & ESSCHER WYSS & ESSCHER WYSS & $\begin{array}{l}\text { GEBER STROK.CO/ } \\
\text { HENGELO }\end{array}$ \\
\hline Nomor & 6358 & 6359 & 6984 & 2074 \\
\hline Tipe & Francis & Francis & Francis & Francis \\
\hline Posisi & Horizontal & Horizontal & Horizontal & Horizontal \\
\hline
\end{tabular}


Iwan Hermawan: Bangunan PLTA Bengkok...

\begin{tabular}{|l|l|l|l|l|}
\hline Daya & $1500 \mathrm{KVA}$ & $1500 \mathrm{KVA}$ & $1500 \mathrm{KVA}$ & $1000 \mathrm{KVA}$ \\
\hline Putaran & $750 \mathrm{RPM}$ & $750 \mathrm{RPM}$ & $750 \mathrm{RPM}$ & $750 \mathrm{RPM}$ \\
\hline Pemakaian Air & $1,37 \mathrm{~m}^{3} /$ det. & $1,37 \mathrm{~m}^{3} /$ det. & $1,37 \mathrm{~m}^{3} /$ det. & $3,025 \mathrm{~m}^{3} /$ det. \\
\hline Buatan & Swiss & Swiss & Swiss & Belanda \\
\hline Tahun & 1921 & 1921 & 1921 & 1922 \\
\hline
\end{tabular}

Sumber: PT Indonesia Power UBP Saguling Sub Unit PLTA Bengkok, 2012

Tabel 2

Data Generator di PLTA Bengkok dan Dago

\begin{tabular}{|l|l|l|l|l|}
\hline \multirow{2}{*}{} & \multicolumn{3}{|c|}{ PLTA Bengkok } & \multicolumn{1}{c|}{ PLTA Dago } \\
\cline { 2 - 5 } & \multicolumn{1}{|c|}{ Mesin 1 } & \multicolumn{1}{c|}{ Mesin 2 } & \multicolumn{1}{c|}{ Mesin 3 } & \multicolumn{1}{c|}{ Mesin 4 } \\
\hline Nomor & $\begin{array}{l}\text { G E N E R A L } \\
\text { ELECTRIC }\end{array}$ & $\begin{array}{l}\text { G E N E R A L } \\
\text { ELECTRIC }\end{array}$ & $\begin{array}{l}\text { G E N E R A L } \\
\text { ELECTRIC }\end{array}$ & $\begin{array}{l}\text { S I T H } \\
\text { SLIKERVEER }\end{array}$ \\
\hline Tipe & $\begin{array}{l}\text { ATH.8.1500M.750 } \\
\text { FORM.S }\end{array}$ & $\begin{array}{l}\text { ATB.8.1500M.750 } \\
\text { FORM.S }\end{array}$ & $\begin{array}{l}\text { ATB.8.1500M.750 } \\
\text { FORM.S }\end{array}$ & . \\
\hline Daya & $1500 \mathrm{KVA}$ & $1500 \mathrm{KVA}$ & $1500 \mathrm{KVA}$ & $1000 \mathrm{KVA}$ \\
\hline Arus & $138 \mathrm{Ampere}$ & $138 \mathrm{Ampere}$ & $138 \mathrm{Ampere}$ & 92 Ampere \\
\hline Tegangan & $6,3 \mathrm{KV}$. & $6,3 \mathrm{KV}$. & $6,3 \mathrm{KV}$. & $6,3 \mathrm{KV}$. \\
\hline Cas $\emptyset$ & 0,7 & 0,7 & 0,7 & 0,7 \\
\hline Beban & $1050 \mathrm{KW} .50 \mathrm{~Hz}$ & $1050 \mathrm{KW} .50 \mathrm{~Hz}$ & $1050 \mathrm{KW} .50 \mathrm{~Hz}$ & $700 \mathrm{KW.50 \textrm {Hz }}$ \\
\hline Putaran & $750 \mathrm{rpm}$ & $750 \mathrm{rpm}$ & $750 \mathrm{rpm}$ & $750 \mathrm{rpm}$ \\
\hline Phasa & 3 phasa & 3 phasa & 3 phasa & 3 phasa \\
\hline Buatan & USA & USA & USA & Holland \\
\hline Tahun & 1921 & 1921 & 1921 & 1922 \\
\hline
\end{tabular}

Sumber : PT Indonesia Power UBP Saguling Sub Unit PLTA Bengkok, 2012

Tabel 3

Data Exeiter / Opweker di PLTA Bengkok dan Dago

\begin{tabular}{|l|l|l|l|l|}
\hline \multirow{2}{*}{} & \multicolumn{3}{|c|}{ PLTA Bengkok } & \multicolumn{1}{c|}{ PLTA Dago } \\
\cline { 2 - 5 } & \multicolumn{1}{|c|}{ Mesin 1 } & \multicolumn{1}{c|}{ Mesin 2 } & \multicolumn{1}{c|}{ Mesin 3 } & Mesin 4 \\
\hline Merek & $\begin{array}{l}\text { G E N E R A L } \\
\text { ELECTRIC }\end{array}$ & $\begin{array}{l}\text { G E N E R A L } \\
\text { ELECTRIC }\end{array}$ & $\begin{array}{l}\text { G E N E R A L } \\
\text { ELECTRIC }\end{array}$ & SMITH SLIKERVEER \\
\hline Nomor & 1029272 & 1029273 & 1265115 & G 30/16 \\
\hline Tipe & $\begin{array}{l}\text { C.06.4-17-750- } \\
\text { FORM.A }\end{array}$ & $\begin{array}{l}\text { C.06.4-17-750- } \\
\text { FORM.A }\end{array}$ & $\begin{array}{l}\text { C.06.4-17-750- } \\
\text { FORM.A }\end{array}$ & $1-3227-1 \mathrm{~B} 1$ \\
\hline Daya & $17 \mathrm{KW}$ & $17 \mathrm{KW}$ & $17 \mathrm{KW}$ & $10 \mathrm{KW}$ \\
\hline
\end{tabular}


PURBAWIDYA $\square$ Vol. $1 \backslash$ No. $2 \backslash$ Tahun $2012 \backslash 195-212$

\begin{tabular}{|l|l|l|l|l|}
\hline Arus & 136 Ampere & 136 Ampere & 136 Ampere & 91 Ampere \\
\hline Tegangan & 125 Volt & 125 Volt & 125 Volt & 110 volt \\
\hline Putaran & $750 \mathrm{rpm}$ & $750 \mathrm{rpm}$ & $750 \mathrm{rpm}$ & $750 \mathrm{rpm}$ \\
\hline Panas Maks & $50^{\circ} \mathrm{C}$ & $50^{\circ} \mathrm{C}$ & $50^{\circ} \mathrm{C}$ & \\
\hline
\end{tabular}

Sumber : PT Indonesia Power UBP Saguling Sub Unit PLTA Bengkok, 2012

Tabel 4

Data Kapasitor di PLTA Bengkok dan Dago

\begin{tabular}{|l|l|l|l|l|}
\hline \multirow{2}{*}{} & \multicolumn{3}{|c|}{ PLTA Bengkok } & PLTA Dago \\
\cline { 2 - 5 } & \multicolumn{1}{|c|}{ Mesin 1 } & \multicolumn{1}{c|}{ Mesin 2 } & \multicolumn{1}{c|}{ Mesin 3 } & Mesin 4 \\
\hline Merek & $\begin{array}{l}\text { G E N E R A L } \\
\text { ELECTRIC }\end{array}$ & $\begin{array}{l}\text { G E N E R A L } \\
\text { ELECTRIC }\end{array}$ & $\begin{array}{l}\text { G E N E R A L } \\
\text { ELECTRIC }\end{array}$ & GENERAL ELECTRIC \\
\hline Tipe & 9L18Bcj 101 & 9L18Bcj 101 & 9L18Bcj 101 & 9L18Bcj 101 \\
\hline Tegangan & 6900 Volt. AC 5 MF & $\begin{array}{l}6900 \text { Volt. AC 5 } \\
\text { MF }\end{array}$ & $\begin{array}{l}6900 \text { Volt. AC 5 } \\
\text { MF }\end{array}$ & 6900 Volt. AC 08 \\
\hline 1 Pak & 600 cycles & 600 cycles & 600 cycles & 600 cycles \\
\hline
\end{tabular}

Sumber: PT Indonesia Power UBP Saguling Sub Unit PLTA Bengkok, 2012 